\title{
PIERWSZY WIDZĄCY \\ (O CZĘŚCI II TRYPTYKU RZYMSKIEGO - ROZPOZNANIA WSTĘPNE)
}

Przedstawiany szkic ma charakter wstępnie rozpoznawczy. Wydaje się, że wydobywany problem może stanowić klucz do myśli i twórczości Jana Pawła II (Karola Wojtyły); zarówno myśli filozoficzno-teologicznej, jak i poetyckiej, przejawiającej się w medytacyjnym dukcie jego pisarstwa. Zarówno od jednej strony (filozofii i teologii), jak i drugiej (poezji) mogłoby to zagadnienie rozróść się do niedużej (?) książki, uwzględniającej narzucające się konteksty. Odgórnie założona poetyka tej wypowiedzi nie umożliwia jednak tak obszernej rozbudowy i gromadzenia dokumentacji hermeneutycznej, zasygnalizowany zostanie zatem problem bez uwzględnienia możliwych konotacji; wątek czekający na swoją kontynuację. Postawa mówiącego w Tryptyku rzymskim przekracza poziom zarówno samej teologii, jak i filozofii, czy sensy poetyckie z nimi współistniejące. Zważając na tę właśnie postawę mówiącego, przyjmuję, że dla prawdy dzieła piszący o nim powinien dokonać pewnej syntezy doboru nielicznych kontekstów wzmacniających wyrazistość problemów.

Prof. dr hab. BernadetTA KuCZERA-CHACHULSKA - Instytut Badań Literackich PAN; adres do korespondencji: ul. Nowy Świat 72, 00-330 Warszawa; e-mail: bernchach@gmail.com. ORCID: http:// orcid.org/0000-0002-1817-9083. 
W drugiej części Tryptyku rzymskiego (Medytacje nad Księga Rodzaju) jakieś nadzwyczajne miejsce zajmuje „widzenie”. Już otwierająca ją część nosi tytuł „Pierwszy Widzący”. Spośród wielu atrybutów Boga Stworzyciela, Boga Ojca, wymieniony (użyty) zostaje ten bardzo rzadki, on staje się poniekąd we fragmencie poematu medytacyjnego Imieniem Najwyższego; Najwyższy jest tu przede wszystkim Widzącym.

„W Nim żyjemy, poruszamy się i jesteśmy” - brzmi pierwszy wers poematu, umieszczony bezpośrednio pod cząstką tytułową (Pierwszy Widzacy). Po przywołaniu (w pierwszym wersie) zdania z mowy św. Pawła na Areopagu pojawiają się kolejne dopowiedzenia, odnoszące się do Tego, Który widzi. Dopowiedzenia otwierane są pytaniem: Kim jest On?

\footnotetext{
Jest jak gdyby niewysłowiona przestrzeń, która wszystko ogarnia -

On jest Stwórcą:

Ogarnia wszystko powołując do istnienia z nicości nie tylko na początku, ale wciąż.

Wszystko trwa stając się nieustannie -

„Na początku było Słowo i wszystko przez Nie się stało".

Tajemnica początku rodzi się wraz ze Słowem, wyłania się ze Słowa.

Słowo - odwieczne widzenie i odwieczne wypowiedzenie.

Ten, który stwarzał, widzial - widzial, ,że było dobre”,

widział widzeniem różnym od naszego,

On - pierwszy Widzący -
}

Widzial, odnajdywał we wszystkim jakiś ślad swej Istoty, swej pełni -

Widzial: Omnia nuda et aperta sunt ante oculos Eius [wszystko odkryte i odsłonięte przed Jego oczami]. (Jan Paweł II, Tryptyk 15; wszystkie podkr. - BK-Ch)

„Niewysłowiona przestrzeń”, ogarniająca wszystko (On jest - ,jak gdyby” niewysłowiona przestrzeń), przedziwne poetyckie porównanie i nie porównanie, bo powiedzenie wprost o Wszechobecności Boga - od zawsze. O „przenikaniu” się każdej drobiny świata $\mathrm{z}$ tą samą, która była na początku. Niewysłowiona przestrzeń zjednoczona z widzeniem w pewien sposób staje się „widzeniem”, zatem „widzenie” jest jakby elementarną tkanką wszechświata i nieskończoności, rodzajem „tła”, ale z pierwszoplanową w pewien sposób rolą, tym co „scala”; paradoksy nazywania nie powinny tu dziwić. On Jest Widzącym, taką teologiczno-hermeneutyczną decyzję podejmuje poeta, ale też teolog, dziś już możemy powiedzieć - święty.

„Początek” łączy się ze Słowem (fakt opisany przez największych teologów), ale tutaj, w pierwszej części Tryptyku... Słowo utożsamione zostaje z widzeniem i wypowiedzeniem - równoważnie - (,Słowo - odwieczne widzenie i odwieczne wypowiedzenie”). Związek „Słowa” i wypowiedzenia w wymiarze teologicznym 
i nieteologicznym jest czymś oczywistym, wydaje się natomiast, że na jedność Słowa i widzenia (zatem również słowa i widzenia) w takim stopniu - i rozumiejącej jednoznaczności - zwrócił uwagę dopiero Jan Paweł II. Jest być może i tak, że to język poezji, poprzedzany przez bycie poetą, umożliwił wypowiedzenie tej prawdy.

Pierwszy Widzący obejmuje Swoim widzeniem każde późniejsze widzenie każdego pojedynczego człowieka; On widzi przede wszystkim, wedle tekstu biblijnego, że wszystko co uczynił „było dobre”. Widzi - powiedzielibyśmy dzisiaj wysoce niezbornie - aksjologicznie; widzenie tworzy jedność z wiedzą (świadomością, kontemplacją) aksjologiczną, w widzenie zatem zaangażowana jest największa głębia Tego, Który widzi. Dlatego widział (i widzi) „widzeniem różnym od naszego”, ludzkiego, cząstkowego. Z tego ludzkiego widzenia wypływają podziały i „destylacje” zmierzające do brania w nawias czy wyłączania przeświadczeń wartościujących, czy z drugiej strony - czynienie z wartościowania upraszczających aktów, ponieważ żaden człowiek nie widzi w sposób tak czysty, jak Bóg; człowiek od wieków nie może sobie z widzeniem wartości poradzić. On „widział widzeniem różnym od naszego" - mówi poeta, papież, święty. Bez uczonych elaboratów. Różnica tego widzenia stanowi otchłań oddzielenia człowieka od Stwórcy, Który widzi i „odnajduje we wszystkim jakiś ślad swej Istoty”. Ale też tu jest możliwa łączność Boga i człowieka, ten człowiek przecież uczyniony został „na obraz i podobieństwo...”.

Nieco dalej w Tryptyku... pojawia się „,widzenie” na zasadzie wzmagającej się refreniczności, wskazuje także na rytmiczne powroty w akcie medytacji, fragment:

Widział widzeniem jakże innym niż nasze.

Odwieczne widzenie i odwieczne wypowiedzenie:

„Na początku było Słowo i wszystko przez nie się stało”,

$[\ldots]$

Słowo, przedziwne Słowo - Słowo przedwieczne, jak gdyby próg niewidzialny

wszystkiego co zaistniało, istnieje i istnieć będzie.

Jakby Słowo było progiem.

Próg Słowa, w którym wszystko było na sposób niewidzialny,

odwieczny i boski - za tym progiem zaczynają się dzieje! (16)

Próg Słowa oddziela świat widzialny od niewidzialnego, Bóg obejmuje go w niewyczerpanej całości; obejmuje go Swoim widzeniem.

Myśl poety-papieża rozwija się dalej, przez wzmocnienia powtórzeń (rodzaj ekspozycji teologicznych treści) dochodzi do „poziomu” ludzkich działań, związanych czy indukowanych tym Widzeniem, które było na Początku.

Tok opowieści w Tryptyku ... zyskuje nagle ton bardzo sytuacyjny, nasycony konkretem podmiotowym, najbardziej charakterystycznym dla wypowiedzi lirycznych: 
Stoję przy wejściu do Sykstyny -

Może to wszystko łatwiej było wypowiedzieć językiem „Księgi Rodzaju”-

Ale Księga czeka na obraz. - I słusznie. Czekała na swego Michała Anioła.

Przecież ten, który stwarzał, „widzial” - widzial, że „było dobre”.

„Widział”, a więc Księga czekała na owoc „widzenia”.

O ty, człowieku, który także widzisz, przyjdź -

Przyzywam was wszystkich ,widzących” wszechezasów.

Przyzywam ciebie, Michale Aniele! (16)

Z najwznioślejszych tematów teologii problem „widzenia” przenosi refleksję osoby medytującej w obręb twórczości człowieka, sztuki; sygnowanej tu dziełem Michała Anioła. Mówiący tak, jak zwraca się w innych miejscach poematu do świata przyrody („Co mi mówisz, górski strumieniu?”, „Gdzie jesteś źródło?”- w części pierwszej), odnosi się do najwyższego rezultatu pracy człowieka, jakim jest dzieło sztuki; w tym wypadku polichromia Kaplicy Sykstyńskiej. Swego rodzaju „naturalnością” działań człowieka jest sztuka, ona wpisuje go niejako w twardy zobiektywizowany porządek świata; tu, w poemacie Jana Pawła II zjednoczona z jego myślą o Stworzycielu, który jest Widzącym. „Księga czekająca na obraz” nie staje się oczywiście zawężeniem pola widzenia do Biblii pauperum, jest otwarciem ogromnej perspektywy hermeneutycznej, w którą wkroczyć może (powinna) sztuka wraz ze swoimi możliwościami rozświetlenia tajemnicy. Artysta uczestniczy (może uczestniczyć) na jakimś skrawku dostępnego światła w widzeniu samego Stworzyciela. Poetycka myśl Jana Pawła II nie jest oczywiście zagarnianiem w obręb nobilitującej przestrzeni sztuki chorej czy nie-sztuki, jest wskazaniem jej pierwotnej natury i źródeł. „Księgę czekającą na obraz" rozumie się tutaj jako hermeneutyczny akt sięgania poza granice ludzkich możliwości rozumienia. W takim widzeniu artystycznej działalności człowieka Jan Paweł II pozostaje bardzo blisko, albo jest nawet w dużym stopniu tożsamy z Norwidowską egzegezą natury sztuki. Zważywszy główny wątek tych rozważań, dość przypomnieć zdanie poety dziewiętnastowiecznego, wyrażające ważną refleksję w całokształcie myśli i postawy tego autora:

Kiedy to będą wiedzieć to będą wiedzieć, że sztuka jest mniej czy więcej dojrzałym widzeniem. (Norwid, Listy 180)

W papieskim Liście do artystów odnajdujemy zdania ściśle łączące się z problematyką widzenia i sztuki w Tryptyku...

[...] dzieła sztuki inspirowane przez Pismo Święte pozostają jakby odblaskiem niezgłębionej tajemnicy, która ogarnia świat i jest w nim obecna. (List cz. 5)

Każda autentyczna inspiracja artystyczna wykracza bowiem poza to, co postrzegają zmysły, i przenikając rzeczywistość stara się wyjaśnić jej ukrytą tajemnicę. Ma swoje źródło w głębi ludzkiej duszy - tam, gdzie pragnienie nadania sensu własnemu życiu łączy się z nieuchwytnym 
doznaniem piękna i tajemniczej jedności rzeczy. Wszyscy artyści zdają sobie sprawę, jak głęboka przepaść istnieje między dziełem ich rąk, nawet najbardziej udanym, a olśniewającą doskonałością piękna, dostrzeżonego w chwili twórczego uniesienia: wszystko, co zdołają wyrazić malując, rzeźbiąc i tworząc, jest jedynie przebłyskiem owej światłości, która na kilka chwil zajaśniała oczom ich duszy. Człowiek wierzący nie dziwi się temu, gdyż wie, że przez moment oglądał ów bezmiar światłości, która ma swoje pierwotne źródło w Bogu. (List cz. 6)

Jan Paweł II, kontynuując problem widzenia w perspektywie ludzkiej, umocowawszy go wcześniej w źródłach Boskiego widzenia, po wprowadzeniu aktualizującej dukt myśli poematu osoby Michała Anioła, prowadzi wątek medytacji dalej (w apostrofie do włoskiego artysty):

Jest w Watykanie kaplica, która czeka na owoc twego widzenia!

Widzenie czekało na obraz.

Odkąd Słowo stało się ciałem, widzenie wciąż czeka. (Tryptyk 17)

Dzieło sztuki jest propozycją dla tego, kto na nie patrzy, by wszedł na tę samą, co w czasie powstawania dzieła (procesu twórczego), drogę widzenia (zobaczenia, patrzenia) artysty. Dzieło jest „ścieżką” widzenia. Przywołany wers Tryptyku... mówi o Słowie obecnym w dokonanej ekspresji malarza, ale można je również odczytać jako metakomentarz, odnoszący się do słowa poetyckiego Tryptyku..., które prowadzi w głąb Księgi. Jego Autor widzi, zatem rozumie - jeśli można tak powiedzieć - w sposób najbardziej osobisty. Rozumienie tylko w ten sposób jest możliwe. Dlatego przywołany zostaje moment ludzkiej reakcji (łączony potocznie z początkiem filozofii) na to co prawdziwe, piękne, dobre.

od zdziwienia idąc ku zdziwieniu (17)

„Czekające widzenie” podprowadza na „próg Księgi”, dopowiada Autor, Księgi Rodzaju - Genesis. W dziele Michała Anioła słowa zamienione zostały w „bogactwo spiętrzonych kolorów”. Relacjonowana przez Medytującego wizja Księgi Rodzaju i biblijnych losów człowieka przeplatana jest rytmicznymi powrotami do „widzenia”.

\footnotetext{
Widzial Bóg (Tryptyk 19)

Oni także [pierwsi ludzie] stali się uczestnikami tego widzenia (20)

Czyż nie chcą odzyskiwać tego widzenia na nowo? (20)

I Michał Anioł znów ogarnia ich widzeniem (25)

On wszystko widzący... (26)
}

Tych kilka przywołań pokazuje źródłowy, pierwotny, wpisany w człowieka od początku porządek. Człowiek, przeznaczony do uczestnictwa w tym co Boskie, jest uczestnikiem „widzenia”; „odzyskiwanie widzenia” staje się zadaniem na epoki 
ludzkiej obecności na ziemi. Jak mówi znakomity teolog: „Istnieć i patrzeć to akty wzajemnie od siebie zależne" (Tugwell 101).

Wszechogarniające i ,wszechuzasadniające” widzenie, zintegrowane przez Autora Tryptyku... z widzeniem artysty, w prosty, bezpośredni sposób indukuje pojęcie prawdy.

Mówi Hans Urs von Balthasar (później, odnosząc się do własnego tekstu: „mottem [tej] części było «Ten, kto więcej widzi, ma słuszność»» - Balthasar 33):

\begin{abstract}
„Kto dostrzega więcej prawdy, ma głębszą rację”. Jest to zgodne ze starochrześcijańską nauką o „logoi spermatikoi” [zarodkach wszystkich rzeczy] rozproszonych w całym ludzkim świecie duchowym - nie w tym sensie wprawdzie, jakoby wykluczające się wzajemnie doktryny i poglądy mogły mieć jednakowy udział w owym rozproszonym Logosie (musiałby on w takim wypadku nieustannie sam sobie przeczyć), ale w takim, że węższe horyzonty włączają się w bardziej rozległe. Ten, kto w swoim horyzoncie zdoła zintegrować najwięcej prawdy, miałby roszczenie do posiadania jej najwyższego osiągalnego poziomu. Byłby, jeśli wolno się tu posłużyć słowami świętego Pawła, nieco ich nadużywając, owym człowiekiem duchowym, który może wszystko osądzać, sam jednak przez nikogo nie jest osądzany $(1$. Kor 2,15$)$, nikt bowiem poza nim nie ma tak rozległego wglądu w prawdę. (Balthasar 11)
\end{abstract}

Hans Urs von Balthasar buduje swój logiczny wywód (a później nieco chyba spekulatywny), wprowadzając go do myśli antyheglowskiej. Tu na marginesie jakby, poza głównym duktem filozofa, pojawia się ponownie ,uzasadnienie” pierwotnego związku rozumienia $\mathrm{z}$,widzeniem”.

Ten dalszy - po widzeniu - etap zadania postawionego przed człowiekiem, dotarcia do prawdy, ujmuje Jan Paweł II we fragmencie Kazania na Areopagu:

Poprzez rozumność cały byt zostaje człowiekowi zadany pod kątem prawdy: jako prawda. Rozumność to nie tylko zdolność poznawczego odtwarzania („odbijania”) przedmiotów na sposób zmysłowy. To zdolność - i równocześnie zadanie „obcowania” z nimi w prawdzie. Odniesienie do wszystkiego w prawdzie i przez prawdę stanowi istotowy rys duchowości, w którym zostaje absolutnie przekroczony cały wymiar poznania zmysłowego. (Wojtyła 34, podkr. Autora)

Jan Paweł II, również wcześniej H. von Urs Balthasar mówią z pozycji wielowiekowej tradycji filozoficznej, pojawiają się rozróżnienia, przez które „pierwotny obraz" (Bóg, człowiek, widzenie) odsłania się jakby przez zagęszczoną siatkę pojęć i problemów, jakie narosły przez wieki; widzenie, poznanie, rozumienie w sytuacji Księgi Rodzaju stanowiły jedno. Autor Tryptyku ..., poeta, pisząc o widzeniu, dotyka jakiejś ,pratkanki”, ogarnia całość.

Problem widzenia w swoich cząstkowych uwikłaniach myślowych, albo próbach całości, bywał podejmowany (np. w filozofii George’a Berkeleya), łączył się często z problematyką percepcji. Rezygnuję z odniesień do tej literatury filozoficznej, ponieważ wobec problemu tak generalnego i zasadniczego, jaki pojawił się w Trypty$k u \ldots$, te podejścia, które pozostają w obrębie wyizolowanej dyscypliny (nawet jeśli 
jest nią filozofia), nie bardzo są w stanie wspomóc egzegezę myśli poety-papieża. Chciałabym jednak wspomnieć wybitną dwudziestowieczną Teorię widzenia Władysława Strzemińskiego; jest ona wykładem szczegółowych obserwacji malarza i teoretyka, którego ambicją było możliwie pełne zracjonalizowanie procesu patrzenia z uwzględnieniem głównie tego, co „naukowo” dopuszczalne, zatem świata materialnego. Strzemiński swoje obserwacje i myśl prowadził absolutnie indywidualnie, ale ich ramę społeczną i naukową „obligację” stanowił wszechdominujący marksizm. Fenomenalna wartość pracy Strzemińskiego wynika z jednej strony z założenia pełnego i tylko empiryzmu dochodzenia do problemów, z drugiej zaś zbudowania swej myśli na odkryciu, że to jak się widzi (jak widzi oko), zależy od tego, kto patrzy (Strzemiński 51/52), idąc dalej można powiedzieć: kim jest ten kto patrzy. Myślenie Strzemińskiego, ograniczone do świata materii, faktycznie daje możliwość przejścia do zrozumienia tych sytuacji w Tryptyku..., o których pisałam wcześniej. Wznosząc się od poziomu widzenia w obrębie materii, analogizując widzenie oka i tego, kto patrzy do struktur coraz wyższych, jeśli chodzi o osobę podmiotu patrzącego (i może po drodze wykorzystując obserwacje fenomenologii, obiektywizujące sferę wewnętrzną, duchową człowieka), dochodzimy do momentu, w którym „widzenie” z poematu Jana Pawła II staje się teologicznym, ale na wskroś zobiektywizowanym i obdarzonym pełnią realizmu tego Widzenia, które było na Początku.

$*$

Jan Paweł II, autor Tryptyku rzymskiego, filozof, teolog, poeta, święty, wchodząc w poemacie w ten wielki Metakomentarz, sam ujawnia niebywały talent widzenia, geniusz o d kryw a ni a. Bo odkrycie w sferze nazywania również, a może bardziej niż gdzie indziej, musi zostać poprzedzone widzeniem. Może najbardziej zdumiewają sytuacje - jak w Tryptyku..., gdzie na pozór podejmuje się przepracowane przez teologię problemy i w rezultacie poczynań (widzenia i wypowiedzenia) poety-papieża i całkowitego podporządkowania słowa widzeniu, pojawiają się zaskakujące odsłony prawd niby znanych, w istocie jednak zupełnie albo niemal zupełnie nowych.

Taki charakter ma w poemacie medytacyjnym, jego drugiej części, obszerny fragment (bardzo ważny dla całości), w którym mówi się o pierwszych ludziach. Przywołuję kilka wersów:

Oni także u progu dziejów

widzą siebie w całej prawdzie:

byli oboje nadzy...

Oni także stali się uczestnikami tego widzenia,

które przeniósł na nich Stwórca. 
Czyż nie chcą nimi pozostać?

Czyż nie chcą odzyskiwać tego widzenia na nowo?

Czyż nie chcą dla siebie być prawdziwi i przejrzyści -

jak są dla Niego?

Jeśli jest tak, śpiewają hymn dziękczynny,

jakieś Magnificat ludzkiej głębi

i wtedy jakże głęboko czują,

że właśnie „W Nim żyjemy, poruszamy się i jesteśmy” -

Właśnie w Nim!

To On pozwala im uczestniczyć w tym pięknie,

Jakie w nich tchnął!

To On otwiera im oczy.

$(20-21)$

Jedno z najdonioślejszych dokonań myśli Jana Pawła II związane jest z teologią ciała, małżeństwa; dokonał on w tej dziedzinie - chciałoby się powiedzieć - jakiegoś istotnego przewrotu, opierając się jednak na literalnym wybrzmieniu Biblii, odkrywając i porządkując, nie naruszył ani jednego zdania Starego i Nowego Testamentu, ten ,przewrót” polegał jedynie na dopatrzeniu, zintensyfikowaniu widzenia tego, co jest zawarte $\mathrm{w}$ tekście biblijnym i ludzkim doświadczeniu. W przywołanym fragmencie z Tryptyku... dokonane zostaje kolejne pogłębienie dzięki wprowadzeniu perspektywy Widzącego i widzenia. Pierwsi ludzie uczestniczą w „widzeniu” Stwórcy, pierwszy grzech spowodował utratę ,widzenia”, po tym fakcie Autor poematu zapisuje zdanie opatrzone pytajnikiem: „Czyż nie chcą odzyskiwać tego widzenia?”. Podnoszenie się z upadku, dzieje człowieka, w rezultacie tak postawionego problemu stają się odzyskiwaniem widzenia; w trudzie, wysiłku. Związek dwojga „odzyskujących widzenie” jest tu jakimś faktem pierwotnym, analogicznie jak faktem pierwotnym jest działanie artysty; jedno i drugie w sposób jednoznaczny, całkowity połączone ze Stwórcą i Jego pierwszym aktem stworzenia. Napisał Norwid w Lapidariach - „Ta tylko, która niańczy i ten co dłuto trzyma” (Norwid, Wiersze 223).

Za tym ,widzeniem" kryje się wszystko, co o sakramentalnym związku dwojga do tej pory teologia powiedziała, ale kryje się również coś więcej - ustalanie proporcji problemów, ich źródłowe sytuowanie... Język poezji, dający autorowi swoistą wolność, w rzeczywistości przyczynia się do istotnego pogłębienia problemu.

Z tej samej szkoły wywodzący się (fenomenologia) Dietrich von Hildebrand mówi (pisząc znakomicie o małżeństwie, acz w języku może bardziej „zużytym” niż język poety i nie poetyckim, ukierunkowanym bardziej na szczegół) o „odzyskiwaniu widzenia": 
Również małżeństwo tym większej wymaga od obojga miłości, im bardziej samo w sobie jest idealne, im bardziej małżonkowie $\mathrm{z}$ natury uzupełniają się w sposób harmonijny, im większa jest miłość, jaką pierwotnie odczuwali do siebie bądź jaka potencjalnie byłaby w ich wypadku możliwa. Jeżeli dana konstelacja dwóch osób umożliwia realizację miłości małżeńskiej w stopniu maksymalnym, to wraz z zawarciem małżeństwa obowiązkiem obydwu staje się ciągłe staranie o urzeczywistnienie tego ideału [...] Muszą unikać wszystkiego, co mogłoby ją [miłość] przyćmić albo przytępić, na przykład zatopienia się mężczyzny w pracy zawodowej, a kobiety w sprawach domowych, przede wszystkim jednak nie mogą pozwolić, by unosił ich prąd bezwładnych przyzwyczajeń i przytępienia. [...] Nie wolno nigdy traktować jako oczywistości tego, że ten, kogo kocham, odwzajemnia mą miłość, że żyje dla mnie, że posiadam w ten sposób coś, co niby wieża góruje nad wszystkimi innymi rzeczami na świecie. (Hildebrand 44)

Wyimek z filozofa (jego książka powstała wcześniej niż prace Jana Pawła II) jest praktyczną niemal wykładnią rozpoznania problemu przez poetę-papieża, ale ten ostatni mocuje ów problem w istotnie pogłębionym rozświetleniu Początków przez wprowadzenie kategorii postępującego w dziejach „widzenia”, którego Autorem jest Stwórca działający przez człowieka. Fakt ten łączy się oczywiście z wyjściowym dla Medytacji nad Księgą Rodzaju: „Wszystko trwa stając się nieustannie” (Tryptyk 15).

\section{BIBLIOGRAFIA}

\section{PODMIOTOWA}

Jan Paweł II. List do artystów. TUM, 2005.

Jan Paweł II. Tryptyk rzymski. Medytacje. Wydawnictwo św. Stanisława BM, 2003.

Wojtyła, Karol. Kazanie na Areopagu, 13 katechez. Wydawnictwo Literackie, 2018.

\section{PRZEDMIOTOWA}

Balthasar, Hans Urs von. Epilog. Thum. Juliusz Zychowicz, WAM, 2010.

Hildebrandt, Dietrich von. Matżeństwo. Tłum. Joanna Kubaszczyk, W drodze, 2017.

Norwid, Cyprian. Pisma wszystkie, t. 8: Listy, zebrał, tekst ustalił Juliusz Wiktor Gomulicki, Państwowy Instytut Wydawniczy, 1971.

Norwid, Cyprian. Pisma wszystkie, t. 2, część druga: Wiersze, zebrał, tekst ustalił Juliusz Wiktor Gomulicki, Państwowy Instytut Wydawniczy, 1971.

Strzemiński, Władysław. Teoria widzenia, Muzeum Sztuki w Łodzi, 2016.

Tugwell, Simon. Osiem błogosławieństw. Rozważania nad tradycją chrześcijańska. Tłum. Wojciech Unolt, W drodze, 1986. 


\section{PIERWSZY WIDZĄCY \\ (O CZĘŚCI II TRYPTYKU RZYMSKIEGO- ROZPOZNANIA WSTĘPNE)}

Streszczenie

Problem „widzenia” w twórczości pisarskiej Jana Pawła II nie został dotąd zobaczony osobno. Ze względu na wyrazistość jego obecności w Tryptyku rzymskim, na tym materiale dokonano wyodrębnienia motywu. Przydatne okazały się konteksty np. Listu do artystów Papieża, Kazania na Areopagu (Karola Wojtyły). Problem „widzenia”, jak wynika z Tryptyku..., pierwszorzędny atrybut Stworzyciela łączy się z kwestią rozumienia sztuki przez Jana Pawła II, a także jego teologią ciała. Stoi w centrum myśli teologicznej, filozoficznej (estetycznej) Papieża i Myśliciela.

Słowa kluczowe: widzenie; Widzący; Jan Paweł II; filozofia; teologia; sztuka; Tryptyk rzymski

\section{THE FIRST SEER \\ (ON THE SECOND PART OF THE ROMAN TRIPTYCH - SOME PRELIMINARY OBSERVATIONS)}

\section{Sum mary}

The problem of "seeing" in the writings of John Paul II has not yet been examined separately. This motif was discerned in the Triptych due to the distinctiveness of its presence. The contexts of, for example, the Pope's Letter to Artists and the Areopagus sermon were useful. The problem of "seeing" (being, as presented in the Triptych, the first attribute of the Creator) is linked to the question of John Paul II's understanding of art, as well as his theology of the body. It is at the very centre of the theological and philosophical (aesthetic) thoughts of this Pope and Thinker.

Keywords: vision; Seer; John Paul II; philosophy; theology; art; Roman Triptych 